\title{
A SUPRESSÃO DO OUTRO NO EPISÓDIO DO A LIBERDADE DE EXPRESSÃO SOB COERCÃO E O QUE PODE O ARTIVISMO QUEER
} SUPRESSING THE OTHER IN QUEERMUSEUM EPISODE: FREEDOM OF SPEECH UNDER COERCION AND WHAT CAN QUEER ARTIVISM DO

Rafael Luiz Zen ${ }^{1}$ 


\section{Resumo}

A partir do fechamento da mostra Queermuseu em 2017, foram percebidas estratégias de manipulação neofundamentalistas que dessubjetivam a expressão individual do discurso artístico queer. Fala-se da liberdade da fala e das tentativas de apagamento do sujeito porque se admite como objetivo principal debater a supressão do outro a partir de uma coerção discursiva que fere a liberdade de expressão. Como objetivos secundários, tem-se: promover a discussão teórica da liberdade de expressão; revelar na linguagem um local de fogo através do discurso artístico; e analisar as obras de Bia Leite, expostas na mostra. Metodologicamente, foram feitas pesquisas bibliográficas, posteriormente correlacionadas com o estudo de caso das obras de Leite. Ao final, percebe-se que, ao abordar o tema da cartografia das diferenças, este estudo encara o artivismo como uma ferramenta discursiva das lutas sociopolíticas, reafirmando a importância da resistência.

Palavras-chave: Artivismo. Arte queer. Liberdade de expressão. Queermuseu. Arte contemporânea.

\section{Abstract}

From the closing of Queermuseum exhibition in 2017, neofundamentalist manipulative strategies are acknowledged because they desubjectivate the individual expression of queer artists. It is talked about freedom of speech and subject's erasing attempts because this work aims to debate the "other" suppression in the dictatorship of the "self" from the impossibility of freedom when in times of coercion. As secondary goals, it is admitted: theoretically discuss freedom of speech; reveal inside language a place of fire through artistic speech; and analyze the work of Bia Leite, exhibited in the show. Methodologically, a bibliographic research was made so it was possible to correlate the study with Leite's work. By its conclusion, when approaching differences cartography, this research faces artivism as a speech tool used by sociopolitical movements, reinsuring resistance's importance.

Keywords: Artivism. Queer theory. Freedom of speech. Queermuseum. Contemporary art. 


\section{Introdução}

Em dezembro de 2017, uma das principais revistas brasileiras a tratar da questão da sociologia da cultura - a Revista Cult (edição 230), trazia em sua capa o título "Arte sob Coerção - Moralismo Privado no Espaço Público". Compreendendo que o que chamamos de arte hoje não é exatamente o que foi denominado como arte ao longo da História, a publicação problematizava os ataques das frentes conservadoras em relação à mostra "Queermuseu - Cartografias da Diferença na Arte Brasileira", exposição coletiva patrocinada pelo banco Santander no estado do Rio Grande do Sul, cuja polêmica envolve o cancelamento da mesma um mês antes do seu término oficial, a partir de manifestações do MBL - Movimento Brasil Livre.

Sobre a polêmica, ela envolveu manifestações de organizações religiosas, uma campanha que pedia o fechamento da mostra - rebaixando a nota de avaliação da página do Santander Cultural na rede social Facebook e uma tentativa de boicote ao banco. As acusações afirmavam que artistas consagrados como Adriana Varejão, Alfredo Volpi, Cândido Potinari, Flávio de Carvalho, Lygia Clark, Alair Gomes, entre outros, promoviam blasfêmia contra símbolos católicos, pedofilia, zoofilia e a sexualização da infância.

A partir da curadoria de Gaudêncio Fidelis, que havia sido curador da Bienal do Mercosul de 2015, a exposição trazia como mote a diversidade e as questões da identidade de gênero, aos moldes de exposições como a "Queer British Art (1861-1967)" em Londres (2017) e a "Hide/Seek: Difference and Desire in American Portraiture" em Washington (2010).

No catálogo da exposição, FIDELIS afirmou que a obra de arte pode ser uma manifestação crítica diante do processo de colonização do país que perturba as relações verticais e eventualmente as horizontaliza por meio de relações reflexivas que promove. Mais do que um recorte temático, a opção pela curadoria artivista faz com que o espectador reflita sobre problemas estéticos e metafísicos do campo social.

Sobre a compreensão moralista do papel da arte, cujas principais críticas dos apoiadores do encerramento da exposição sugeriam uma volta à arte bela - aquela cujas bases se estabelecem na moral e nos bons costumes, TIBURI (2017a, p. 12) afirma que dessubjetiva a expressão individual do artista em um espaço simbólico (discursivo, narrativo, de fala) onde a "crítica necessária à obra cede lugar ao ódio contra a própria ideia de uma expressão livre".

Sendo regra estatal ou parâmetro moralista para a vida, a censura deve ser debatida e amplamente discutida porque visa o controle das mentalidades no sentido que mina a percepção das individualidades, das formas de perceber o mundo e das formas de sentir e se relacionar com o outro.

A construção da experiência estética, ética e política mediante o contato com as artes passa a ser alvo de destruição em contextos autoritários. Admitindo que o caráter autoritário desenvolve-se sempre que se abre um espaço coletivo de imposição, afirma-se que pessoas e instituições podem fomentar modos antidemocráticos de expressão por promover o apagamento e silenciamento do outro. Nesse contexto, por ser inerentemente uma ferramenta discursiva que não se contém diante do autoritarismo, a arte torna-se insuportável porque diz aquilo que se quer negar ou esconder. 
Nesse contexto, chama-se de artivismo o tipo de resistência poética que reformula a experiência do fluxo coletivo das vozes, criando canais alternativos para a circulação democrática do pensamento crítico. Sobre a possibilidade de insurgências políticas mediante a manifestação artística, André Mesquita (2008) ainda define que a arte político-ativista pode ser compreendida como uma prática que tenta partilhar uma ideia marginal através da intervenção sensível, buscando formas de visibilidade.

Pode-se chamar de abismo o lugar entre a arte contemporânea e o autoritarismo. E é nesse lugar que os artistas brasileiros viram-se novamente em 2017. Impotente diante do cancelamento, o público brasileiro viu exposições, peças de teatro e performances sendo expostas, polemizadas, ridicularizadas e canceladas por instituições e grupos que, conforme aponta TIBURI (2017a, p. 12), estão "confusos em relação à arte nas suas vidas, (quando) devemos nos perguntar em que estágio se encontra a capacidade de cognição, de compreensão e de sensibilidade no Brasil de 2017".

A violência institucional contra artistas, curadores, colecionadores e o público, tanto quanto a luta pelo espaço público livre e democrático, constituem duas frentes do mesmo embate: a lembrança histórica da censura à arte e aos discursos no Brasil do século XX e o receio de observar a possibilidade de retorno a um momento autoritário em relação à liberdade de expressão.

Deste modo, a presente pesquisa justifica-se pelo contexto histórico que discute e por propor questionamentos acerca da liberdade da fala e das tentativas de apagamento do "outro" (díspar) na ditadura do "eu" (conservador), trazendo a confluência entre debates teóricos e a proposição de um estudo de caso a partir das obras "Travesti da Lambada e Deusa das Águas" e "Adriano criança viada bafônica", da série "Criança Viada", de autoria de Bia Leite - uma das artistas mais criticadas e discutidas a partir da polêmica em relação ao fechamento do Queermuseu.

Em nível profissional e pessoal, justifica-se também por se aliar a um panorama de diversos outros textos publicados por artistas a partir das reverberações da polêmica do fechamento, tomando o espaço das falas acadêmicas para propor justamente o que a linguagem - quando livre - pode fazer: apresentar pontos de vista que pretendam diluir os discursos de ódio e apresentar alternativas de pensamento que se pautem na liberdade de existir e de se expressar.

Desta forma, baseia-se a fundamentação deste artigo a partir da seguinte pergunta: o que pode o artivismo queer - como prática de manipulação da linguagem poética no direcionamento de discursos políticos e de ação - em relação à liberdade de expressão e da fala? Pergunta, pois admite que é papel do pesquisador científico apresentar contrapontos ao pensamento vigente e dominante.

Para formular uma possível resposta a este questionamento, assume-se como objetivo central deste estudo debater a supressão do outro na ditadura do eu, a partir da impossibilidade de prática da liberdade de expressão quando em momentos de coerção pela militância neofundamentalista e conservadora. Como objetivos secundários, admite-se: promover a discussão teórica da liberdade de expressão em tempos autoritários; revelar na linguagem um local de fogo através do discurso artístico; e analisar as obras "Travesti da Lambada e Deusa das Águas" e "Adriano criança viada bafônica", de Bia Leite, sob a ótica da coerção. 
Definindo como fonte de informação um recurso informacional que guie e auxilie o estudo, o estudo prevê metodologicamente uma pesquisa bibliográfica de fonte primária (em artigos pessoais em periódicos científicos e entrevistas) e outra de fonte secundária (em livros e revistas), posteriormente correlacionando as teorias propostas com o estudo de caso das obras de Bia Leite.

Para que a trajetória teórica seja possível, serão utilizados como bibliografia principal os autores: HANNAH ARENDT (2007), e o conceito de público e privado; HAKIM BEY (2001) e os lugares do discurso; ANDRÉ MESQUITA (2008) e a potência do artivismo; FRANCISCO BOSCO (2017) e a liberdade de expressão no novo espaço social brasileiro; bem como os artigos encontrados na Revista Cult (2017, ano 20, n. 230), de organização de Marcia Tiburi.

Citando novamente o texto de TIBURI (2017a, p.13), cujo dossiê assistia com receio a arte sob coerção a partir do moralismo privado no espaço público, é possível afirmar que o real papel do texto acadêmico/científico é o de "abrir os olhos e ver além das viseiras autoritárias" que conduzem suas manifestações à supressão da subjetividade, pautando suas ações pela ótica da conduta normativa - dessubjetivando qualquer possibilidade de alteridade livre.

Por ser constituída num campo de relação entre saberes, a arte pode ser compreendida mediante o poder discursivo que carrega, pois atua no campo da linguagem. Instaurando um regime de verdades discursivas ou sugerindo novos pontos de vista, é a partir da linguagem que as ações do mundo e de sua esfera pública podem ser questionadas, debatidas e socializadas.

\section{Desenvolvimento teórico}

Em seus escritos, HAKIM BEY (2001) aborda a democracia dos discursos como um ato necessário à liberdade, observando que nós, do tempo presente, estamos predestinados a viver dominações tanto territoriais quanto psicológicas. Embasado por um pensamento crítico em relação às estruturas sociais da fala, seus espaços de sociabilização e seus modos de troca, o autor propõe que obras artísticas configurem um espaço de debates entre a reflexão e a manutenção do status quo.

Pretendendo traçar um retrato do modelo social predominante no tempo presente, ele o descreve como um maligno ciclo infinito que incuba o Estado, um Estado após o outro, um espaço onde "nada, além de um martírio inútil, poderia resultar de um confronto direto com o Estado terminal, esta megacorporação, o império do Espetáculo e da Simulação" (BEY, 2001, p. 06).

Por esse viés, da impotência do confronto direto com o Estado, ele ainda pressupõe que sempre haverá artistas dispostos a defender um discurso pelas vias artísticas, sejam elas mainstream ou independentes, através de financiamentos públicos ou privados. $O$ autor, então, sugere um termo para definir esse tipo de manifestação que surge como uma ocupação de espaços por meio do discurso do contrafluxo. A esse tipo específico de espaço, que retém o poder de contaminar as narrativas vigentes de subjetividade, Bey (2001) intitula zona autônoma temporária.

Para o autor, as zonas autônomas temporárias (também chamadas de TAZ temporary autonomous zone) são espaços que conquistam áreas de imaginação, 
emergindo e desaparecendo, cedendo lugar para novas obras, novas manifestações, novas guerrilhas. Para exercer todo o seu potencial de espaço partilhador de experiências sociossensíveis, deve utilizar espaços/discursos assimilados pelos dispositivos de controle para problematizar novos modelos de fala.

Para os fins desse trabalho, a exposição de arte - principalmente em seu caráter artivista - será considerada uma $T A Z$ quando propõe situações culturais e imaginárias efêmeras que permitem o acesso a pensamentos de contra-ataque ao status quo. Muito mais do que mera polêmica, esses campos artísticos fazem emergir de forma espontânea uma voz para determinado grupo de pessoas que propõe a diversidade cultural e a individualidade como valor partilhável.

MESQUITA (2008) discute que o artivismo pressupõe a recuperação de um espaço de fala através do espírito de resistência, tornando a estética artística uma criação política. Afirmando que esse tipo de engajamento social impulsiona para o encontro possível da arte com as formas políticas da vida, o autor infere que a criação de táticas discursivas acontece pela "ausência ou enfraquecimento das formas tradicionais de espaço público e das privatizações da comunicação e da cultura, sendo atualmente ampliadas a um nível nunca antes visto historicamente" (MESQUITA, 2008, p. 45).

Para adentrar essa esfera de confronto e reconstituir relações sociais mediante a manipulação da linguagem, um artivista inserido em uma zona autônoma temporária cria um "projeto de cooperação e um paradigma estético-político que canaliza as competências artísticas para intervir no centro da própria situação social e política do seu tempo histórico" (MESQUITA, 2008, p. 48).

Por fim, a TAZ como tática artística prevê a liberação psicológica do dispositivo: momentos e espaços de ação onde a liberdade do discurso não é apenas possivel, mas existente. Contra a alienação do conservadorismo, essas zonas não pregam a utopia social, mas a autonomia no tempo presente.

\subsection{A autonomia do "eu" no campo social}

A partir da constatação de que a linguagem é produtora de realidades, de subjetividades e veículo de transmissão de valores, BOSCO (2017) introduz uma análise sobre o espaço midiático do país - o qual chama de novo espaço público brasileiro - campo por excelência de disputas políticas.

Ainda afirmando que a entrada do sujeito na ordem da linguagem representa sua entrada na ordem de uma determinada estrutura social, o autor complementa que a manutenção dos termos da linguagem contribui para a manutenção do status quo social. Observando espaços de sociabilização da fala, afirma-se que é nesse espaço de resistência ainda aberto, que "a contracultura emerge como crítica comportamental, denunciando os mecanismos de poder presentes no cotidiano e na intimidade" (BOSCO, 2017, p. 74).

Admite-se, aqui, que o conceito de "disputa política" nada tem a ver com a esfera partidária, mas da potência discursiva que a política como ciência das relações pressupõe. Esse conceito é encontrado em ARENDT (2007), em seu livro "A Condição Humana", onde a autora investiga questões que dizem respeito à esfera pública como local no qual o homem, por meio de palavras e ações, adquire o estatuto político de cidadão. 
Discutir o surgimento desse novo tipo de relação insere o homem em um contexto político plural, uma espécie de advento de domínio social. Estar em público é, portanto, dominar sistemas de relacionamento, pois - para as relações sociais - mostrar-se é um ato de manifestação. Se viver significava estar entre os homens e morrer significava deixar de estar entre os homens, o ato da existência pressupõe uma esfera de convívio cujo patamar de comparação seja a aparência.

Trazendo à tona os conceitos de labor (aquilo que biologicamente é a condição da existência do homem na Terra), trabalho (o ato da manufatura dos objetos que mediam nossa existência) e ação (a potencialidade da fala democrática e da construção de espaços de troca no âmbito social), ARENDT (2007) afirma que esta última - nosso poder de conexão entre as pessoas através do pensamento - constitui uma atividade que se exerce diretamente entre os homens, através de atos e palavras, e visa fundar e preservar os corpos políticos.

Para a autora, cada uma destas atividades, segundo a sua natureza, situa-se em um lugar no mundo. Por isso, para relações autoritárias ou totalitárias, há algumas atividades que devem ser escondidas na privacidade do lar e outras que devem vir a público. Esse critério é determinado pelo mundo das aparências e pelas estruturas dominantes de poder.

A ação, por sua própria natureza de revelação do ser e do outro, necessita da luz do espaço público. Afirmando que todo vivente pretende revelar a sua própria imagem na esperança de que essa revelação constitua a capacidade máxima de relação com o outro, ARENDT (2007) ainda infere que a competência de nos relacionarmos com os outros na esfera pública pressupõe o espaço democrático da aparência para que todos os indivíduos possam ver e serem vistos por outros.

Nesse contexto, a vida política (no sentido da vida possibilitada pelo discurso e pelas capacidades narrativas) é o início de algo totalmente inédito dado à imprevisibilidade das ações desencadeadas pelos discursos. Se, para a autora, o nascimento do homem é a fonte de toda novidade no mundo porque o próprio homem é um ser singular - diferente de todos os que existiram antes dele, então se pode afirmar que o espaço da aparência constitui-se num campo de protagonismo das relações, marcado essencialmente pela pluralidade.

Cada ser que se revela no espaço social pressupõe espectadores que garantam a realidade do mundo, havendo a necessidade - para a esfera pública - que exista um nível de equilíbrio entre as tensões existentes. Frente os conflitos de interesses próprio deste espaço, irrompem problematizações sobre a inexistência de uma única verdade factual, permitindo que se garanta a multiplicidade de olhares.

Quando ARENDT (2007) afirma que a principal característica dos negócios humanos se constitui da coletividade, conclui que este mundo é marcado por uma pluralidade de visões e de atores, que se alternam entre os papéis de emissor (comunicar/ser visto) e receptor (receber informações/observar). O espaço social da aparência - que podemos também chamar de espaço da visibilidade - é fundamentalmente um mundo habitado por seres destinados a verem e serem vistos em seus protagonismos.

Logo, se não existe um único ser ao qual não corresponda um espectador, é pressuposta a afirmação de que nada exista no singular, pois a pluralidade é a marca 
de um mundo que se dá a conhecer pela aparência. O espectador - esse "outro" em relação ao "eu" que está em mim - só pode ver em parte aquilo que aparece, porque o que aparece adquire também uma espécie de disfarce. É nos pontos em comum entre os homens que reside o potencial humano.

Compreender a diferença, portanto, busca constituir um novo espaço alargado de experiências. Quando se dissipa a ilusão do fac-símile, rompe-se subitamente a esfera da aparência pela construção de novas realidades e identidades. $O$ que nos move a aparecer não está ligado meramente a funções internas - uma condição humana isolada da sociedade, mas o impulso inerente de autoexposição como validação social.

Para ARENDT (2007), o medo de observarmos o cão de Pavlov - o ser condicionado das teorias behavioristas - tomando contornos assustadoramente reais residia na ideia de que, a partir de discursos autoritários, o ser humano viesse a substituir a liberdade de ação pelo condicionamento do comportamento humano em uma sociedade que trocaria o livre discurso pela norma/normatividade.

Desta forma, pela necessidade da exposição de si como ferramenta de relacionamento e diálogo, afirma-se que a proliferação de discursos de ódio (normativos e totalitários) é coercitiva porque impossibilita a liberdade de praticar-se a democracia das vidas e das falas como corpo coletivo.

\subsection{Pelo artivismo do fogo: crítica à autoridade e oposição à normatividade da cultura}

BOSCO (2017) afirma que a tensão sobre os discursos sociais ativistas constitui a expressão fundamental da crítica à autoridade, observando que geralmente se opõe à normatividade da cultura em seu sentido amplo: ao paradigma masculino, branco, ocidental, heterossexual. Analisando principalmente as lutas identitárias das manifestações brasileiras do período entre 2013 (luta das ruas) e 2017 (luta das redes), o autor afirma que os discursos da frente identitária operam no âmbito do simples reconhecimento de que haja dispositivos de poder ao serviço do controle da fala.

Buscando teorias clássicas como de Guy Debord e Michel Foucault, BOSCO (2017) define poder como uma rede de práticas de controle institucionais, agindo sobre formas de vida e cultura, que transforma experiências de conformação de gênero e sexualidade em espetáculos ditados pela tática da dominação. Desta forma, sugere que as lutas identitárias tenham emergido também como uma resposta ao poder dominador que institucionaliza modelos de conduta.

Para os movimentos identitários - sejam eles das comunidades feministas, queer, negra, etc. - o poder é encarado como uma espécie de força invisível que mina condições justas de reconhecimento, rebaixando suas condições objetivas e subjetivas. $O$ que $O$ artivismo identitário busca é o assentimento social mediante a manifestação poética - um espaço discursivo que sugere ao outro reconhecê-lo.

O reconhecimento da identidade (sendo também o reconhecimento da diferença) é o "campo de luta primordial dos movimentos sociais identitários: o preconceito social, as ideologias originárias do poder masculino, branco, anglo-saxão, heterossexual, cisgênero" (BOSCO, 2017, p. 78). Nesse sentido, o reconhecimento da identidade emerge como o reconhecimento da legitimidade do discurso. 
Conceituando o que é um discurso, FOUCAULT $(2009$, p. 08) já afirmava que se trata de uma "existência transitória destinada a se apagar, sem dúvida, mas segundo uma duração que não nos pertence". Apesar de ser impreciso definir o início ou fim de uma manifestação discursiva, pode-se afirmar que os textos são construções sociais que influenciam na atmosfera social e na forma como são moldadas as narrativas do sujeito.

Isso pressupõe dizer que - a partir de uma análise sobre a manifestação do pensamento em dado espaço temporal - a construção de discursos é ao mesmo tempo controlada, selecionada, organizada e redistribuída por procedimentos que têm por função conjurar seus poderes e perigos.

O autor discorre que as relações de poder postas pelas instituições (escolas, quartéis, famílias, grupos sociais) foram marcadas pela disciplina, que traz consigo uma maneira específica de punir - a exclusão daquele que não encontra seu posicionamento ideológico concordante com o discurso vigente. Pela disciplina (imposta ou pela autodisciplina) se estabelecem relações de opressor/oprimido, mandante/ mandatário e persuasivo/persuadido, onde poder e verdade são peças consonantes no mesmo jogo estratégico.

Ainda em FOUCAULT (2009), afirma-se que a modernidade apresentou duas forças atuantes no cenário social: o poder disciplinar (no âmbito da relação entre os indivíduos) e o poder advindo da sociedade estatal (no âmbito do coletivo). Se o poder disciplinar surge como substituição do poder pastoral (como herança do campo religioso), no campo político a sociedade estatal substitui o poder soberano.

Sob essa ótica, é correto afirmar, portanto, que a população é vista como sujeito das necessidades e aspirações coletivas, consciente daquilo que se quer, mas inconsciente em relação ao que se quer que ela faça. Assim, o interesse individual (do sujeito) e o interesse geral (da população) atuam como forças capazes de governar e programar políticas identificadas por aspectos subjetivos. $O$ caráter subjetivo dos discursos é inerente à produção da fala e das narrativas.

Para a ótica foucaultiana, o ato do discurso pressupõe três tipos de mediações/ interdições: não se tem o direito de dizer tudo (pelo tabu do objeto), não se pode falar de tudo em qualquer circunstância (como se presenciássemos um ritual da circunstância) e não se pode falar de qualquer coisa (pois há certa exclusividade do sujeito que fala, que se chama de direito do privilegiado). Para BOSCO (2017), os espaços onde essa coerção é mais acirrada são geralmente os que pressupõem a liberdade dos discursos políticos e das sexualidades.

Nesses campos específicos, observa-se uma ordem inversa da liberdade de expressão: ao invés de ser uma ferramenta transparente e neutra no qual a sexualidade se desarma e a política se pacifica, é a partir da linguagem que os privilegiados exercem alguns dos seus mais temíveis poderes. Isso porque o discurso está intimamente relacionado ao desejo de representação, não sendo apenas aquilo que traduz as lutas ou sistemas de dominação, mas aquilo pelo que se luta, o tipo de poder que as lutas identitárias querem apoderar-se sobre. Lutar pela possibilidade do discurso é ampliar o lugar de fala do "eu" díspar, prevendo espaços sociais para a livre discussão da alteridade. 
Peter Pál Pelbart (2015), citando a obra de Foucault, acrescenta que as diversas formas da arte podem constituir zonas limítrofes entre a razão/normatividade e a loucura/liberdade, experiências-limite que preparam para além do ambiente cultural um diálogo interno com aquilo que a própria cultura vigente rejeita. Para ele, a literatura pode representar uma fala dos confins que apresenta seus efeitos para fora do próprio campo artístico.

Acredita-se, então, em uma arte possível para a exterioridade da obra, no poder transgressivo da linguagem pela fala anárquica que cruza e mina todos os outros discursos. Nesse sentido, utilizando um termo de Blanchot em PELBART (2015), afirma-se que a arte pode constituir uma "parte do fogo" da sociedade, uma instância imaginária composta pelos temas que a própria cultura reduz às cinzas, nega a convivência e que emerge como um incêndio interno pelo diálogo das artes.

Observa-se, no entanto, a impossibilidade de que toda manifestação artística reative essa parte do fogo, pois o fenômeno apenas acontece quando existe a retomada da expressão recuperada do sistema social e do consumo, aquela fala que não pode ser vencida pelas estruturas do pensamento burguês e da sociedade normativa, uma arte que conserva sua exterioridade porque revela outros lados, outras formas de pensar e de sentir.

Portanto, para esta pesquisa, será compreendida como "arte do fogo", a linguagem como tentativa de reerguer as ruínas da liberdade dos discursos, agindo imediatamente na fresta entre a provocação e a linguagem. Flutuando entre os espaços sociais, as palavras se tornam também coisas, corpos, sons, e as frases deslizam por um plano muito mais dos fragmentos do "outro" do que da totalidade do "eu".

Resgatar na arte a dimensão sensível do diálogo, libertar a palavra do corpo-neutro que a aprisiona e trazer ao exterior a potência da coletividade são também funções do artivismo. Através do fogo imposto pela expressão artística, sua lava em erupção confere mobilidade aos signos antes petrificados/condicionados, abalando as verdades instituídas e fazendo emergir consigo o lado mais vulcânico da linguagem.

\subsection{Moralismo privado no espaço público}

Dois meses após as polêmicas envolvendo o Queermuseu, Gaudêncio Fidelis, curador da mostra, publicou um artigo de seis páginas na Revista Cult de número 230, intitulado "Não à censura: a criminalização da produção artística e os danos ao patrimônio cultural brasileiro". No texto, FIDELIS (2017, p. 14) afirma que "no dia 10 de setembro de 2017, um acontecimento extraordinário mudaria para sempre nossa percepção da censura e da deturpação da verdade para fins obscuros - o fechamento oficial da exposição Queermuseu".

Afirmando que o intuito da exposição era fazer uma incursão artística sobre questões relacionadas à identidade de gênero, à diferença e à diversidade (incluindo a própria diversidade da forma artística), o curador apresentava um conjunto de trabalhos representativos da amplitude estética de várias regiões do país. Ela, que seria a primeira mostra dessa envergadura na América Latina, e apenas a quarta no mundo, reuniu 264 obras de 85 artistas brasileiros. 
FIDELIS (2017) ainda acrescenta que uma obra de arte, independentemente do mérito artístico que lhe seja atribuído pela crítica ou pela historiografia, é considerada em essência patrimônio da humanidade e, portanto, deve ser preservada e protegida de danos físicos e morais. Afirmando que o conjunto reunido pelo Queermuseu é representativo do patrimônio artístico brasileiro, percebe-se que um processo de difamação dessas obras foi posto em curso para invalidá-las perante o espaço público - desde a sociedade brasileira até a comunidade artística internacional.

Como fins de exemplificação, toma-se, por exemplo, a publicação de Cesar Augusto Cavazzola Junior (2017), intitulada "Santander Cultural promove pedofilia, pornografia e arte profana em Porto Alegre", cuja crítica à exposição compreende que ela se distanciava de um suposto verdadeiro objetivo da arte, a consagração do belo. $O$ autor afirma:

Gaudêncio Fidelis, o curador da exposição, pode até ter doutorado em história da arte, mas certamente arte não é a sua especialidade, apenas confusão. Isso será explicado a seguir com base no que ele escreveu para o encarte de apresentação dos trabalhos. Primeiramente, ele fala na diferença como alteridade. Isso não passa de um curto-circuito cerebral dos ditos especialistas em arte contemporânea que já há tempos se distanciaram do verdadeiro objetivo da arte: a consagração do belo. Hoje o artista precisa causar impacto, e só. (CAVAZZOLA JUNIOR, 2017, s/p)

Intitulando o curador de "depravado", o autor ainda afirma que o fechamento da exposição retoma a ideia da arte como forma de transcender o barbarismo e as limitações do imaginário humano em defesa da civilização, criando barreiras normativas para a conservação (ou conservadorismo) política(o). Resgatando uma fala de Fidelis sobre o objetivo da exposição, que pretendia subverter a consolidação de uma política de identidade essencialista permitindo a derrubada de barreiras de gênero sem necessariamente impor outras, CAVAZZOLA JUNIOR (2017) afirma justamente o contrário, que esse tipo de prática perverte a arte, fazendo com que o não normativo seja introduzido ao patamar da norma.

Discursando sobre uma política de identidades, o autor ainda afirma que os únicos movimentos que impõem tais diferenças são os movimentos das minorias. Ao discursar que "eles (os movimentos identitários e os grupos de minoria) não querem igualdade coisíssima nenhuma, mas a criação de amplos poderes para formação de classes de intocáveis" (CAVAZZOLA JUNIOR, 2017, s/p).

CAVAZZOLA JUNIOR (2017) também coloca em xeque o papel da tradição na sociedade, cuja opinião revela que as minorias identitárias possuem como único intuito a subversão da norma como uma espécie de imposição da diferença, dando destaque à oposição de ideias justamente para torná-las a nova igualdade. Para ele, ao buscar a igualdade, os militantes da identidade buscam a homogeneização da diferença - algo inadmissivel para a manutenção de velhos poderes.

Não percebendo a ironia do oximoro - figura de linguagem em que se combinam palavras de sentido oposto que parecem excluir-se mutuamente, mas que, no contexto, reforçam a expressão, CAVAZZOLA JUNIOR (2017) crava um modo impraticável de compreensão da identidade, pois sugere que a discussão da diferença sirva para instaurar "modelos de ser diferente", ou seja, observa o fenômeno da alteridade 
pela ótica da repreensão do molde. No entanto, o que as lutas identitárias promovem é justamente o oposto do molde, a possibilidade de estruturas mais fluidas de existência e pertencimento.

Inferindo que - para as militâncias identitárias - "a tradição não tem qualquer papel numa sociedade a não ser oprimir desejos insaciáveis e estabelecer parâmetros normativos para enquadrar as pessoas em determinadas categorias" (CAVAZZOLA JUNIOR, 2017, s/p), o autor encara a normatividade como um ato de defesa da civilização, como se houvesse realmente um conjunto de paradigmas intransponíveis que fizessem com que o corpo social pudesse funcionar de forma coesa e organizada.

Defendendo uma democracia do eu em detrimento da liberdade do outro, parece que os moralistas pretendem desmoralizar as lutas queer quando, entre tantas outras afirmações, discursam que há uma confusão entre processo criativo e necessidade de expor intimidades. Para eles, a arte contemporânea passa por um momento de curto-circuito cerebral dos ditos especialistas em arte, que não compreendem mais o objetivo principal do ato artístico: expor o belo.

Para FIDELIS (2017), no entanto, o conteúdo da exposição não foi selecionado por um suposto curto-circuito cerebral, mas pela possibilidade das obras proporem confrontos com o espectador. Intitulando a decisão de encerramento da exposição pelo banco Santander (que a sediava) como um desprezo pela verdadeira narrativa dos trabalhos, o curador ainda aponta que outra narrativa - a da depravação - foi inscrita sobre eles com o objetivo de transformá-los em protagonistas de um discurso maléfico de conteúdo criminoso, atribuindo à arte o papel de defensora de crimes como a pedofilia e a zoofilia.

Privada da averiguação visual (haja vista que o banco reteve as obras em um processo de censura que durou 30 dias), a sociedade brasileira adentrou ao que o curador chama de "uma mentira articulada e construída para enganar" (FIDELIS, 2017, p. 17).

A jornalista Eliane Brum (2017), em sua coluna de opinião ao jornal El País de 18 de setembro de 2017, intitulado "Gays e crianças como moeda eleitoral", concorda com o pensamento de Fidelis quando afirma que:

\footnotetext{
O que se pode afirmar sobre milícias como o MBL é que elas têm um projeto de poder - ou têm um poder que pode servir a determinados projetos de poder. $\mathrm{O}$ poder destas milícias está em mostrar que são capazes de se comunicar com as massas e, portanto, de influenciar tanto eleitores quando odiadores, num momento histórico em que estas duas identidades se confundem. E este é um enorme poder, que claramente tem sido colocado a serviço de políticos e de partidos tradicionais. Além e principalmente, claro, de a serviço de seu próprio benefício. A descoberta de que temas "morais" são uma excelente moeda de barganha não é prerrogativa do MBL e de seus assemelhados. (BRUM, 2017, s/p)
}

A questão levantada por BRUM (2017) é pertinente ao recorte temático da supressão do outro pelas ditaduras do eu porque reflete uma estratégia de manutenção discursiva do poder. Ao compreenderem o potencial narrativo da polêmica envolvendo uma exposição que claramente dialogava com as múltiplas nuances de "ser quem se é", as milícias contrárias ao Queermuseu levantaram suposições preconceituosas como plataforma de ataque. Logo, a supressão da liberdade de expressão torna-se um 
estratagema de supressão da liberdade de existir.

Sobre a questão da liberdade, BOSCO (2017) afirma que para uma convivência minimamente saudável na esfera social, é necessário que sejam criados mecanismos que prevejam a existência de corpos díspares anterior a qualquer liberação da fala, pois o discurso - como já debatido acima - é um órgão vivo no cerne social, que pulsa e (re)transforma todas as relações intrapessoais e interpessoais. Ele afirma:

(...) o que se deseja é eliminar qualquer pretensão de universalidade de um particular específico (...) na medida em que seu direito à igualdade implica a eliminação de qualquer pretensa universalidade. Isso posto, retorna o problema do conflito entre dois princípios igualmente garantidores de liberdade: liberdade de expressão e direito a reconhecimento social e modos de vida não tradicionais. (BOSCO, 2017, p. 101)

É por isso que as lutas identitárias se intensificam tanto no novo espaço social brasileiro - a Internet, com seu núcleo de redes sociais digitais já consolidadas e expandidas. Munidos, pela primeira vez, de um espaço democrático de fala, os movimentos identitários operam no âmbito do reconhecimento. Reconhecer e ser reconhecido passam a serem pautas públicas porque influencia diretamente no modo como os corpos, os sujeitos e as relações são vistos e moldados no espaço social.

O que esses movimentos tentam resgatar é um ambiente de descentralização do poder, isto é, das práticas de controle não institucionais - tão atuantes sobre formas de vida e cultura, como as experiências de conformação de gênero, por exemplo.

Em um campo afetivo do imaginário humano, as lutas identitárias surgem e se justificam como uma resposta à dominação de uma estrutura social que só respeita um único modelo, um hiato entre falas. Seja através do campo artístico (o Queermuseu, por exemplo), performático (a Marcha das Vadias) ou até mesmo linguístico (hashtags e memes), BOSCO (2017) aborda essas manifestações pela ótica do contra-ataque:

"É nesse hiato de possibilidades, no espaço de resistência ainda aberto, que a contracultura emerge como crítica comportamental, denunciando os mecanismos de poder presentes no cotidiano e na intimidade, constituindo-se como expressão fundamental de crítica à autoridade em seu sentido amplo: ao paradigma masculino, branco, ocidental, heterossexual. Surgiram, assim, manifestações artísticas de forte dimensão contracultural (...)". (BOSCO, 2017, p. 75)

Sejam feministas, queer, raciais, dentre outros, o que todos esses movimentos identitários possuem em comum é uma luta contra o poder (totalitário, normatizante, impraticável) e pelo reconhecimento (da subjetividade, das formas de existir, da liberdade de transitar e de expressar-se). O poder, como condição invasiva que mina toda e qualquer condição justa de reconhecimento, rebaixa determinados grupos e indivíduos diminuindo sua subjetividade pela comparação com o modelo normativo. Reconhecer a existência de esse poder e lutar por um espaço mais democrático de fala nada mais é, nesse sentido, do que a condição fundamental para o desenvolvimento do eu.

Quando se trata de discursos de incitação ao ódio ou normatizantes, infere-se que a violência queer pelos olhos da militância conservadora é obrigá-la a reconhecer esse outro que desponta à imagem do "eu" pela relação de alteridade: obriga o moralista a reconhecer um "outro amoral". Ao transformar artistas, ativistas e público 
em geral em cultuadores da pedofilia e da zoofilia, pervertidos reunidos em torno de uma exposição, os protestantes invalidam qualquer tentativa de aproximação igualitária. Como afirma BRUM (2017):

\begin{abstract}
Assim, testemunhamos um fenômeno de ilusão na semana passada. O problema do Brasil já não era a desigualdade nem a pobreza que voltou a crescer. Nem mesmo o desemprego. Nem a crescente violência no campo e nas periferias promovidas em grande parte pelas próprias forças de segurança do Estado a serviço de grupos no poder. Nem o desinvestimento na saúde e na educação. Nem a destruição da floresta amazônica e o ataque aos povos indígenas e quilombolas pelos chamados "ruralistas". Nem projetos que mexem em direitos conquistados na área trabalhista e da previdência sendo levados adiante sem debate por um governo corrupto. Não. De repente, na semana passada, o problema do Brasil tornou-se, para milhões de brasileiros, a certeza de que o país é dominado por pedófilos e defensores do sexo com animais. Agora, são artistas que devem ser perseguidos, presos e até, como se viu em algumas manifestações nas redes sociais, mortos. E não só artistas, mas também quadros e peças de teatro. O problema do Brasil é que pedófilos querem corromper as crianças e transgêneros querem destruir as famílias. (BRUM, 2017, s/p)
\end{abstract}

Não somente o prejuízo causado à exposição - sua censura e o cerceamento da liberdade de expressão - é a herança do fechamento do Queermuseu, mas o apagamento da subjetividade pelo ataque discursivo. $O$ fato torna-se um fator incômodo para as lutas identitárias - a tentativa de reciclagem de um padrão centrado na família tradicional "que a bancada da Bíblia tenta vender como a única família possível, formada por um homem e uma mulher" (BRUM, 2017, s/p). Incomoda porque ainda prevê um único modelo familiar, amplamente debatido e esclarecido nas últimas décadas do século $X X$.

Para a autora, em momentos como esse é necessário que a arte continue apostando na resistência e no fortalecimento dos movimentos culturais. Ao solicitar espaços de fala através do discurso artístico, o Queermuseu adentra a disputa do campo da linguagem porque exige para si um diálogo possível. Enquanto alguns gritam pedófilo, é preciso que a classe artística escute e responda de maneira a fazer a manutenção desse diálogo. Nessa estrutura de poder, são os movimentos normatizantes que ganham com o esvaziamento (apagamento) das palavras.

\title{
30 eu político: discursos de manutenção da subjetividade
}

Para a arte que surge a partir do século XX, a crise moderna faz com que ambos - criador e público - encarem a experiência do sujeito a partir de novas condições de pensamento estético, social e político. O corpo, então, passa a ser uma condição discursiva do sujeito, ferramenta de contato com o mundo exterior e com os outros, passível de ser questionado, problematizado e desconstruído.

Para uma democratização dos corpos a partir das provocações da arte, surgem múltiplos agentes discursivos: degradados (como na performance de Maikon Kempinski - DNA de DAN), participantes (como em La Bête de Wagner Schwartz), reconstruídos (como em $O$ Evangelho segundo Jesus, rainha do céu - de Natalia Mallo), resgatados (como em "Travesti da lambada e deusa das águas", de Bia Leite). 
A assimilação do corpo livre pela arte, portanto, pressupõe a relação entre subjetividades e condutas normativas. Marcando a complexa relação entre a experiência física do mundo, é possível notar a existência de um corpo-identitário, um organismo que se caracteriza pela possibilidade territorial de que a subjetividade do ser humano exista no campo do real. Pautado por uma lógica informacional, os corpos inevitavelmente comunicam, mostram-se, conduzem a uma tradução passivel de tradução ao outro.

Desta forma, é imprescindivel que o corpo-signo seja livre - para que possa ser visto e interpretado livremente. A linguagem torna-se essencial à sociedade do controle porque a subjetividade é construída como processo coletivo: a construção do si ocorre também no campo social, da construção das falas, discursos e narrativas que conferem sobre o corpo práticas de domínio e expressão.

Como consequência, as relações entre o "eu e o outro" - ou seja, entre o "meu corpo e o corpo do outro" - implicam inerentemente um caráter político, pois formam uma dimensão que molda e segmenta a individualidade. Para o campo sociológico, a construção do sujeito não é produto meramente psíquico, mas das redes de conexões que a vida social promove.

Portanto, quando se fala sobre campos de produção de subjetividades - esse espaço íntimo do indivíduo onde ele exerce sua liberdade de opinião e expressão, além de se relacionar com o mundo social ressaltando suas marcas singulares, suas crenças e valores compartilhados na dimensão cultural - trata-se essencialmente de relações de produzir-se e ser produzido. Em atos totalitários, moralistas ou coercitivos, o poder disciplinar torna-se exercício de controle quando o corpo do outro pode ser tomado como agente polemizador através da subversão de certos tipos de corpos e sujeitos, tomados como perversões da conduta normativa.

Para Silvia Tedesco (2006), defender a subjetividade é compreender os processos de produção dirigidos à geração de modos de existências, ou seja, de agir, sentir e dizer o mundo. $O$ sujeito como produto discursivo prevê sua livre existência a partir de estruturas de linguagem, sistemas simbólicos no qual o sujeito estaria imerso. Para a construção igualitária do "eu", a linguagem é uma prática que transforma a realidade porque atribui aos relacionamentos humanos modos de conduta e convívio.

Para o objeto de estudo em questão - o Queermuseu e, mais precisamente, as obras "Travesti da lambada e deusa das águas", de Bia Leite (Figura 01) e "Travesti da lambada e deusa das águas" e "Adriano criança viada bafônica" - a investida discursiva por parte da militância conservadora e suas acusações criminosas são tomadas como coerções discursivas cujo intuito seja a descaracterização das subjetividades queer, bem como da deslegitimização da arte como processo instaurador de debates. 


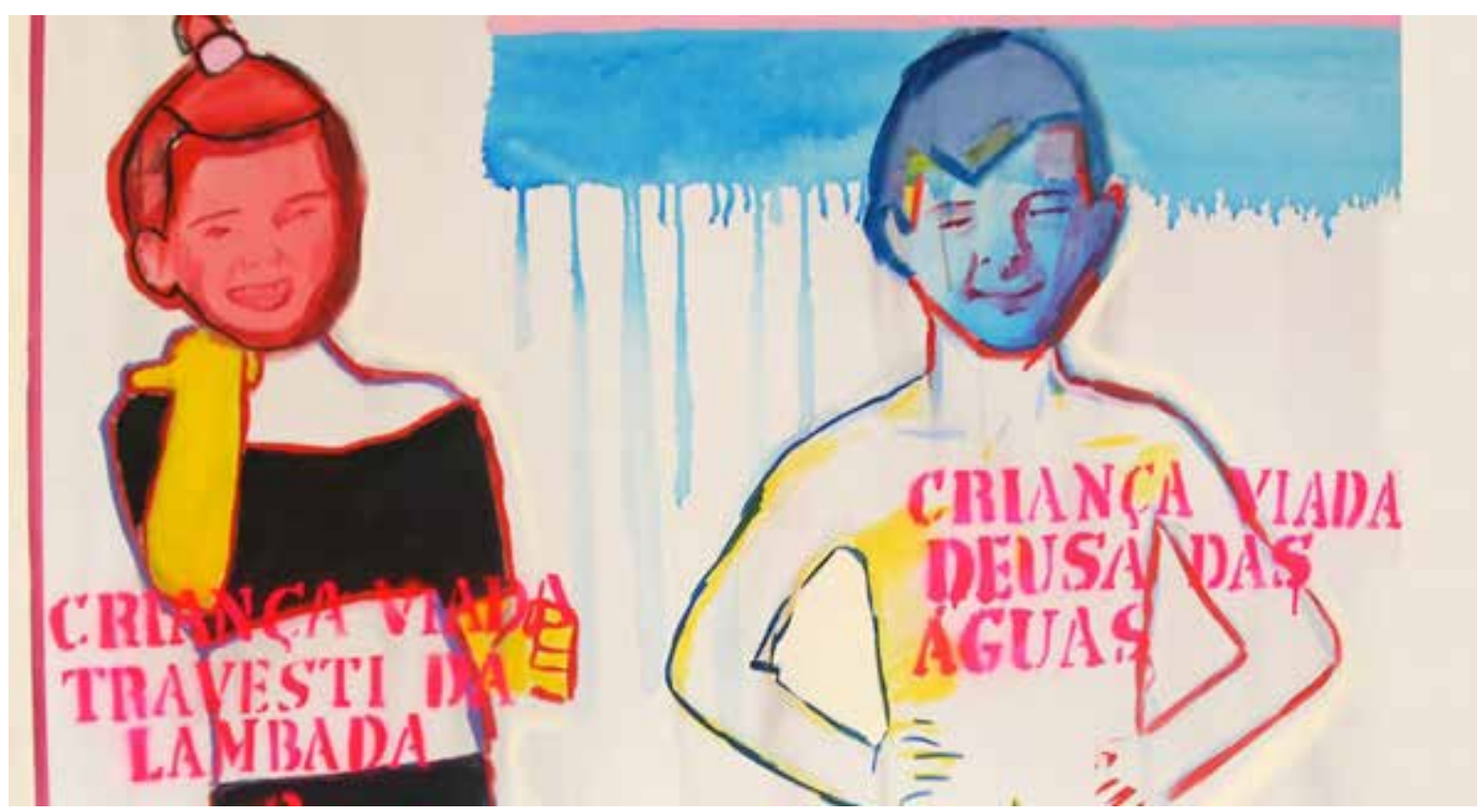

Fig. 1 - "Travesti da lambada e deusa das águas".

Fonte: Bentes, 2017

Pautando-se pela ótica da produção de modelos a serem seguidos (neste caso, o modelo heteronormativo e, consequentemente, machista e misógino), pautava-se na época da polêmica uma tentativa de produção de um sujeito-produto, fidedigno a um modelo geral de conduta: uma produção seriada, homogeneizante.

TEDESCO (2006) ainda afirma que existem momentos em que segmentos do processo de produção do sujeito instalam-se como uma estranha modalidade de produção, instaurando um espaço de debates que invalida a opinião do outro (neste caso, a possibilidade de que diferentes identidades de gênero não sejam perversão de caráter) e impossibilita qualquer convergência possível entre narrativas sociais e liberdade de identidade.

Nesse jogo discursivo, a própria realidade (onde, claramente, o sujeito encontra formas múltiplas de compor-se) é alterada porque se dispersa entre as múltiplas falas, estabelecendo jogos de poder na tentativa de emergir um sujeito-produto resultante: no caso das militâncias pró-fechamento da exposição, o sujeito pervertido cuja conduta deve ser abolida ou remediada; no caso das obras expostas no Queermuseu, a confluência e liberdade das identidades de gênero e homoafetivas. No campo prático resultante desse embate, é a crença nos discursos que pautará a conduta dos corpos (sobre e entre eles).

TIBURI (2017b), afirma que as crenças sustentam a vida mental que se expressa como linguagem. É a partir da administração dos discursos, portanto, que se torna possível a administração das teorias, dos corpos, das práticas de si. Para a filósofa, "teorias científicas dependem de crenças do mesmo modo que as teorias populares nos ajudam a organizar o cotidiano" (TIBURI, 2017b, p. 28).

As explicações nascem das ideias em que se acredita, ato que vale para todas as esferas da vida: religiosa, moral, econômica, política. A explicação como mediadora das crenças vale, inclusive, para o campo artístico. Muito mais do que uma ideia, 
instância ou conceito, a arte pode ser compreendida como um campo social onde ocorre um tipo de experiência complexa que atinge o lugar do que se crê.

Quando se entra em contato com a arte, o sujeito se orienta mediante suas teorias prévias (tanto populares quanto científicas) para traduzir a modalidade da experiência que está em jogo. Definindo que "as artes se apresentam como proposições materiais que providenciam problemas onde eles não existiam" (TIBURI, 2017b, p.28), ela ainda pressupõe que a obra seja um desprogramador de hábitos mentais, possível em sua totalidade somente para aquele espectador situado no campo externo da resistência.

Ora, não é justamente isso que o fechamento do Queermuseu promoveu? Uma resistência à experiência completa do sujeito queer e do sujeito espectador em suas inúmeras formas de subjetividade. Compreendendo que a resistência aparece e desaparece conforme as definições de conduta e gosto do seu tempo, pode-se perceber que a história da arte e das imagens está sempre adiantada em relação à história do gosto, principalmente pelo alargamento das possibilidades da arte contemporânea, que pode servir - inclusive - para a desconstrução de toda e qualquer norma, gosto ou pressuposto.

Da mesma forma que o urinol de Marcel Duchamp (na época incompreendido, hoje reverenciado) fez da ironia uma ação estética, trazendo tanto um caráter performativo do objeto artístico quanto sua transubstanciação enquanto heresia (negação oficial da crença), também a obra de Bia Leite transcreve no objeto uma modalidade discursiva que prevê através da linguagem (a simples constatação da existência de uma criança viada) uma ironia de gênero, sua transmutação em corpo acessível e possível. Esse discurso, porém, atinge e fere o moralismo das militâncias antigênero e anti-homoafetividade, que percebem na subjetivação da criança e da infância um campo impossível à compreensão da alteridade.

\subsection{Crianças viadas e a existência de outros corpos}

Para analisar a obra de Bia Leite, serão debatidos os artigos "Criança Viada: o que está por trás da obra que gerou revolta?" de Júlia Warken (2017) para o portal M de Mulher, "Nós, LGBT, já fomos crianças e isso incomoda" de Tiago Dias ao portal Uol Entretenimento, "A arte que virou pornografia aos olhos dos neofundamentalistas" de Ivana Bentes para a Revista Cult Online, "Qual o problema em ser criança viada?" de Bruno Costa ao site Vice Brasil e "Não há arte possível para a gente de bem" de Daniela Name ao Portal O Globo.

NAME (2017) inicia seu artigo narrando uma exposição na qual cada obra de arte foi tida como um ataque premeditado à ordem, onde cada artista foi considerado pervertido, bandido ou prevaricador, a partir da qualuma patrulha civil, de plantão do lado de fora, intimidava as pessoas para que não entrassem no local. Afinal, pela ótica coercitiva, tudo que não é pelo bem (pela norma, pela regra, pelo comportamento premeditado) compactua pelo mal. A autora ainda provoca: 


\begin{abstract}
suas principais peças de propaganda ideológica. Nas paredes e no espaço, obras de Piet Mondrian, Emil Nolde e Oskar Schlemmer, entre outros grandes nomes da arte moderna. Esteticamente, eles representavam a ruptura com a ideia de verossimilhança e com o sistema de representação ordenado e hierárquico vigente desde o Renascimento. Simbolicamente, apontavam para a arte como um horizonte de ambiguidades, de opacidade e de ficção; um campo sem compromisso com o real; um impulso sempre faminto de liberdade e de utopia. E, é claro, um perigo avassalador para a intolerância e o discurso monocórdio de Hitler. A exposição "Arte degenerada" deu ao ditador a chancela para a destruição de obras dos artistas participantes e também de Picasso, Kandinsky e Matisse - todos vistos como vetores "judaico-bolcheviques". O resto da história conhecemos bem - ou ao menos deveríamos: obras de arte queimadas, escondidas, destruídas. Artistas e pensadores fugindo ou morrendo. (NAME, 2017, s/p)
\end{abstract}

É nesse ponto de ruptura com a ideia de verossimilhança que o texto da jornalista se pauta. A verossimilhança, fac-símile do real proposto, cria espaços discursivos que não admitem ambiguidades. Para as militâncias, o diferente - aquele que é imprevisivel porque não atua abaixo da norma - é algo a ser aniquilado porque não há um parâmetro de aproximação. A diferença torna-se, então, um abismo intransponivel entre o mundo real (a centralidade da experiência humana a partir da experiência do eu) e o mundo fictício (do outro, ao qual o "eu" só pode adentrar mediante a suposição, a empatia, o jogo).

Quando se afirma uma pesquisa sobre as cartografias da diferença, a exposição pressupõe um mapeamento das subjetividades, debatendo principalmente a importância da alteridade como zona de encontro - e não de afastamento e apagamento. A mostra não levanta bandeiras, mas estende o debate à sociedade pelo mecanismo da arte porque promove múltiplas visões sobre a conquista da diversidade, sobre formas de habitar o corpo além de colocar em debate a liberdade de existir. Para a arte contemporânea, a galeria é sempre mais potente quando não tenta apaziguar o discurso pela ótica da normalidade.

O que a mostra se propunha realizar é a cartografia da diferença humana, não exclusivamente gay ou trans, mas a problematização da alteridade como condição do homem social. A autocensura demonstra que "estamos perdendo a capacidade de compreender a metáfora e a ficção" (NAME, 2017, s/p). No caso da arte contemporânea, a autora ainda defende que se perdeu a capacidade de compreender que não há mais um espelho possível para um mundo de imagens ordenadas, que só existe na cabeça "dessa gente honrada que odeia gays, pobres e negros. Dessa gente honrada que odeia. Ponto" (NAME, 2017, s/p).

Portanto, a estratégia dos grupos ultraconservadores é de associar a arte ao mal. Ou seja, atacam não só a liberdade de expressão, mas demostram uma vasta ignorância em relação às formas disruptivas da arte falar sobre comportamento, crenças e valores. Para a patrulha fundamentalista, se combate o artivismo com o "ódioartivismo" (BENTES, 2017, s/p).

BENTES (2017) ainda salienta o direito fundamental de "não ver", ou seja, não frequentar locais expositivos cujos conteúdos são considerados violentos, pervertidos ou sexualizados. Porém, para os fundamentalistas, é necessária a censura: ao impedir e destruir o direito de ver.

Obras como "Travesti da lambada e deusa das águas" e "Adriano criança viada 
bafônica" propõem o incômodo da aparência. Ser e parecer, na ótica da obra, compõem o direito à performatividade da alteridade. Propor a supressão e eliminação da obra, portanto, significa propor a supressão e eliminação do outro, negar seu percurso histórico e, principalmente, invalidar esses modos de vida.

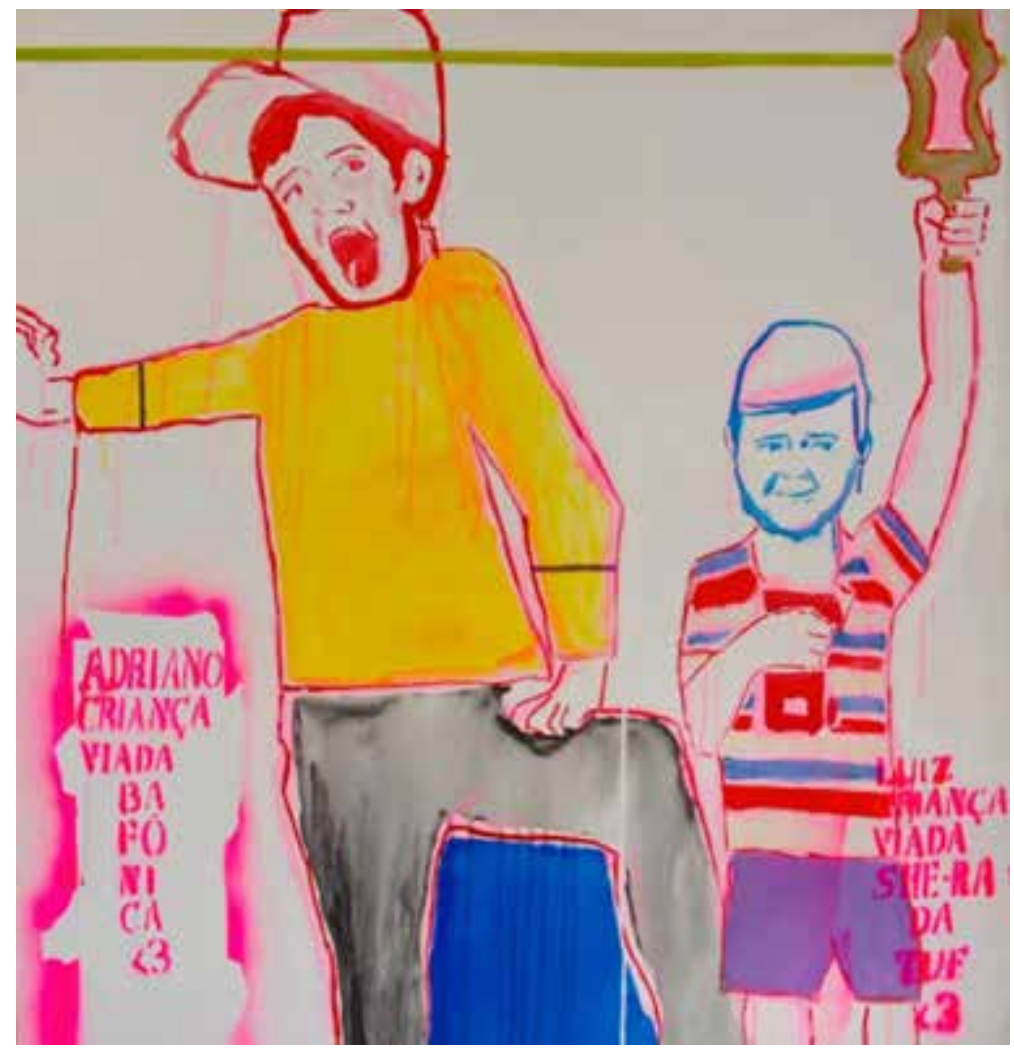

Fig. 2 - "Adriano criança viada bafônica" de Bia Leite. Fonte: Warken, 2017.

"O horror diante da expressão de temas e questões produz o ódio dos que imputam aos artistas um poder de influência sobre os corpos e escolhas identitárias", afirma BENTES (2017, s/p). Como se fosse possível a incitação da subjetivação pelo simples contato com a forma de expressão do outro, as manifestações coercitivas não compreendem que esse tipo de exposição, ao invés de obrigar um modelo de pensamento (trocar um molde por outro), provoca a reflexão e o questionamento acerca da intolerância, do preconceito, da violência diante do outro e diante das diferenças.

A invalidação de sujeitos que lutam para se expressar é o signo de uma sociedade que não suporta a alteridade, ou seja, a existência de outros, com os quais se deve conviver em sociedade. As gravuras coloridas de crianças em poses e trejeitos não heteronormativos, como nas obras em questão, incomodam porque ampliam novas formas de pensamento.

O que a artista pretendia, portanto, era a discussão sobre a validação social da criança homossexual em um contexto linguístico que empregava gírias do próprio universo gay: a possibilidade de respeito à criança travesti, deusa, bafônica, viada. Muito mais do que sua exposição sexual, o que Leite buscava era o empoderamento do sujeito queer na infância. A autora ainda afirma: 


\begin{abstract}
"Nas telas expostas todas as crianças sorriem e o texto enaltece e empodera essas crianças desviantes -- finalmente! -- chamando-as de deusas ou nomes de super-heroínas. A linguagem da pintura também nos insere na História com orgulho e força, diante de uma sociedade que nos quer invisíveis. Nós, LGBT, já fomos crianças. Esse assunto incomoda porque nós nunca viramos LGBT, nós sempre fomos. Todos nós devemos cuidar das crianças, não reprimir a identidade dela nem seu modo de ser no mundo, isso é muito grave". (LEITE in DIAS, 2017, s/p)
\end{abstract}

A necessidade de visibilidade a crianças cuja vivência foge aos padrões heteronormativos foi justamente o ponto de embate entre a artista e o moralismo. Dizê-las viadas não pressupõe um atestado de que estejam inseridas no contexto do sexo pervertido porque as identidades de gênero e performatividade sexual são aspectos diferentes que emergem da mesma problematização. Nesse contexto, são os adultos (espectadores ou não da arte) que fazem leituras sexualizadas e LGBTfóbicas do entorno discursivo do qual fazem parte. Como infere WARKEN (2017), não são só adultos que sofrem preconceitos, que são agredidos por não seguirem a heteronormatividade, mas também o foco das obras: a criança.

A pressão normativa sobre o sujeito pode ser sofrida em qualquer idade e, por isso mesmo, a importância dela como discurso ativista, bem como a existência da exposição: sua parte do fogo, essa complexa instância imaginária composta de temas (sempre identitários, que habitualmente chama-se de discurso de minoria, mesmo representando a maioria) que a própria cultura reduz às cinzas. É justamente por compreender que há forças que negam a convivência livre entre os corpos que o artivismo instaura esse incêndio interno pelo diálogo que promove com as artes.

COSTA (2017) aborda a exposição pela ótica da força coercitiva e do ser social em construção quando afirma que a sociedade, através dos seus mecanismos, instaura níveis de repressão do sujeito, sua inibição em relação ao próprio aprendizado de si (seu gênero, sua sexualidade, seu corpo). Nesse sentido, os valores conservadores - na tentativa de conservar um status quo pouco includente e frequentemente excludente - dificultam o processo de comunicação livre e aberto.

Para compreender o contexto histórico da homossexualidade (e toda sua trajetória de doença institucionalizada para sua compreensão como performatividade) é necessária a possibilidade do debate, para que os sujeitos queer tenham mais liberdade de se comportar, se expressar, se mostrar como o melhor de si, não o pior do outro. Para o artivismo, a cartografia das diferenças não é só uma questão de sexualidade, mas uma das frentes da sociopolítica.

FOIGEL (in COSTA, 2017, s/p), afirma que mesmo pesquisando a transgeneridade nas crianças e quebrando paradigmas, mesmo sabendo que o sujeito se inscreve por características que vão muito além da genitália, "a sociedade insiste em achar que o problema está fora (no outro) e não dentro, em nós mesmos e nas nossas escolhas".

Pelas tentativas de barrar a viadagem, em todas as fases da vida, o que se percebeu a partir das polêmicas do Queermuseu foi um embate entre o pensamento autoritário que pressupõe a verdade única (o discurso deles) e todas as outras falas que não enxergam problema algum em se ser criança ou adulto viadas (o nosso discurso). 


\section{Conclusão}

Para TIBURI (2017b), o trabalho artístico também constitui um trabalho filosófico de pensamento, consistindo em dizer e desdizer mitos e condutas de comportamento para fazer refletir. Porém, para a filósofa, um sistema de crenças rígidas baseado em certezas sólidas e verdades absolutas não apenas torna-se impraticável do ponto de vista da subjetividade, mas faz com que os adeptos à conservação da normatividade não aceitem esse jogo discursivo.

Tanto o corpo híbrido (a criança viada que, ao mesmo tempo, é masculino e feminino no campo da transformação) quanto a arte híbrida (que pode fazer pensar, refletir, contemplar - do belo ao grotesco, em suas infinitas formas) são produtos de discursos que causam "alegria intelectual aos animados e mal-estar aos indispostos" (TIBURI, 2017b, p. 30). Para ela:

O que chamamos de arte é um universo de objetos (pinturas, literatura, poesia, cinema, performance, ready made, happenings) que causam um efeito concreto de estremecimento na ordem estabelecida por meio da ironia. É nesse sentido que a arte provoca a realidade. Cria um outro mundo que necessariamente põe em xeque o que estava dado como verdadeiro. Porque tudo o que é pode não ser. Muitas pessoas não se sentem confortáveis diante de obras de arte, justamente porque elas abalam o nosso conforto mental, o nosso sistema de crenças, o que é dado e tomado como certo e verdadeiro. (TIBURI, 2017b, p. 30)

Assim como entendemos o outro a partir das mediações possiveis relacionadas ao caráter subjetivo - educação, religião, conduta, sexualidade, gênero, tantos outros - também assim entendemos a arte. Há horizontes de compreensão prévios ao ato de perceber uma obra de arte, bem como ao ato de perceber o outro. Como uma das formas de combate a esse tipo de poder totalitário é que surge a potência da arte contemporânea, que persiste por realizar a função metafísica essencial da arte: retirar o outro do óbvio imediato, fazer sentir e pensar a partir do alargamento da subjetividade no sentido de uma autorreflexão crítica.

"O moralismo impediu a experiência da emancipação do pensamento e da sensibilidade à qual as artes nos conduzem", afirma TIBURI (2 017b, p. 31). O diálogo reflexivo - seja mediante a arte, a filosofia, a sociologia, a política - preserva o sujeito de adentrar experiências autoritárias. Isso porque, ainda pelo pensamento da filósofa, a arte é sempre uma proposição que se coloca como uma pergunta e resposta ao mesmo tempo.

Ao configurar uma linguagem de mão dupla - pergunta/problemática e resposta/ experiência, a manifestação artística nega todos os poderes totalitários porque permite aos sujeitos olharem para o mundo de maneira horizontalizada: nela, o corpo, a nudez, o espaço, o tempo, as relações, o gênero, as classes, as raças, o sujeito como um ser complexo e, por consequência, livre, viram elementos de contestação para regimes de poderes absolutos.

Defendendo a tarefa de resistir, TIBURI (2017b, p. 31) por fim conclui que "as obras desconfortam, desestabilizam, abrem corações e mentes para a aventura do conhecimento que exige a coragem da presença". Ora, não seria justamente isso que a obra de Bia Leite traz à tona? A coragem da presença da alteridade, do outro como 
sujeito diferente e ao mesmo tempo com o mesmo direito da aparência. A infância - um dos objetos máximos dos discursos moralistas - surge então como um espaço passivel de desconstruções.

Portanto, a partir da pergunta: "o que pode o artivismo queer em relação à liberdade de expressão e da fala?", admite-se que é papel do artivista apresentar contrapontos ao pensamento vigente e dominante - masculino, branco, ocidental, heterossexual. Como encontrado nas obras de Bia Leite, o debate acerca das manifestações artísticas pode ser encarado como um contra discurso que atua pela ótica da problematização e da reflexão.

Ao trazer à tona a imagem da criança viada (da sua possibilidade de existência, das suas condições de sociabilização como sujeito tanto físico quanto discursivo), as obras absorvem um discurso deliberadamente livre de moldes e preconceitos. Instaura um diálogo direto com o espectador, fazendo-o analisar a infância sob a ótica da manifestação do gênero, tanto no campo artístico quanto político e social.

Assumindo como objetivo central deste estudo debater a supressão do outro na ditadura do eu, a partir da impossibilidade de prática da liberdade de expressão quando em momentos de coerção pela militância neofundamentalista, compreende-se a partir do pensamento de ARENDT (2007), BEY (2001), MESQUITA (2008), BOSCO (2017) e TIBURI (2017a, 2017b) algumas correlações possíveis.

Finalmente, infere-se que a liberdade de vida - como encontrado em BOSCO (2017) - deve ser sobressalente à liberdade de expressão/coerção quando se trata das subjetividades do outro, quando coloca em risco a liberdade de uma existência efetiva: social, política, expressiva, artística e discursiva. No contexto de setembro de 2017, tanto a liberdade de vida quanto a liberdade de expressão foram cerceadas por divergências de nível pessoal/subjetivo, quando as militâncias ultraconservadoras não propuseram formas de diálogo com a alteridade, mas seu apagamento.

Promovendo a discussão teórica da liberdade de expressão em tempos autoritários, tido como um dos objetivos específicos do estudo, o presente trabalho pretende estimular o pensamento crítico em relação à arte contemporânea e suas possibilidades. Conforme supracitado, um dos papéis da arte é justamente desestabilizar o lugar comum e propor ao espectador novas formas de confronto, a partir de problematizações de cunho político, social, ambiental, sexual, etc - promovendo o alargamento da subjetividade mediante a visão crítica dos comportamentos sociais e da vigilância constante sobre os corpos.

Chama-se de autoritário todo comportamento que impõe definições excludentes de um "eu" de um "outro", que negue formas de subjetivação do sujeito (seu campo de diferenças) e dificulte ou impossibilite a manifestação de discursos contrários aos preceitos normalizantes vigentes. Ao extrapolar os limites da galeria e atacar artistas e conteúdos artísticos pelo viés da subversão moral, o que as militâncias conservadoras fizeram foi a tentativa de silenciamento e invalidação de formas não normativas de vida.

Afirma-se, então, que o artivismo pode criar um local incendiário no ambiente cultural (outro objetivo específico da pesquisa), um espaço que confira visibilidade a assuntos negligenciados pela pauta pública e pelo poder autoritário, revelando-se a partir da linguagem artística. O que choca em obras como "Travesti da Lambada e Deusa das Águas" ou "Adriano criança viada bafônica" é seu potencial de deflagrar formas de infância apagadas pela tradição histórica heterossexual. 
Por isso, ao analisar as obras de Bia Leite sob a ótica da coerção (último objetivo específico proposto), afirma-se que as polêmicas do museu queer atingem um local de fogo ao contrariar o pensamento autoritário negando o pressuposto da verdade absoluta (um único molde comportamental que prevê a condução programada dos corpos) e revelando novas falas: da criança viada, do corpo livre, da igualdade sexual e de gênero, da subjetividade, da alteridade como ponto de equilíbrio.

Por fim, abordando o tema da cartografia das diferenças como um pressuposto social básico, este estudo trouxe a obra de arte (principalmente a contemporânea e artivista) como uma das ferramentas discursivas das lutas sociopolíticas, reafirmando a importância da resistência frente à supressão do outro livre pela ditadura do eu conservador.

Observa-se a liberdade de expressão sob a coerção de militâncias neofundamentalistas quando estas interpretam o mundo a partir de verdades infalíveis e universalmente validadas, buscando má intenção onde não há. Também se pondera sobre $o$ aspecto ultraconservador de seus atos, impondo ideologias tradicionais e conservadoras cujo objetivo é a manutenção do status quo. O que, então, pode o artivismo queer é configurar-se como um espaço autônomo de fala, um mecanismo reflexivo tão necessário em tempos ainda tão cerceadores.

Ao ativar faíscas e aproximar o mundo do outro do mundo real - que é hétero, homo, neutro, binário, feminino, masculino, drag, trans, bi, pan, múltiplo e complexo - o artivismo ainda demonstra que a arte contemporânea pode configurar-se como um campo imaginário que propõe - muito mais do que formas de representação modos de coexistência.

\section{Referências}

ARENDT, Hannah. A Condição Humana. Rio de Janeiro: Forense. Universitária, 2007.

BENTES, Ivana. A arte que virou pornografia aos olhos dos neofundamentalistas. Portal Revista Cult, 2017. Disponivel em: <https://revistacult.uol.com.br/home/ arte-que-virou-pornografia-aos-olhos-dos-neofundamentalistas/>. Acessado em 11 de março de 2018.

BEY, Hakim. TAZ: zona autônoma temporária. (coleção Baderna) São Paulo:

Conrad, 2001.

BOSCO, Francisco. A vítima tem sempre razão? Lutas identitárias e o novo espaço brasileiro. São Paulo: Todavia, 2017.

BRUM, Eliane. Gays e crianças como moeda eleitoral. Jornal El País, 2017. Disponível em: <https://brasil.elpais.com/brasil/2017/09/18/opinion/1505755907_773105. html>. Acessado em 10 de março de 2018. 
CAVAZZOLA JUNIOR, Cesar Augusto. Santander Cultural promove pedofilia, pornografia e arte profana em Porto Alegre. Locus Online, 2017. Disponível em: <http://locusonline.com.br/2017/09/06/santander-cultural-promove-pedofilia-pornografia-e-arte-profana-em-porto-alegre/>. Acessado em 12 de março de 2018.

COSTA, Bruno. Qual o problema em ser criança viada? Portal Revista Vice, 2017. Disponível em: <https://www.vice.com/pt_br/article/qvj9kq/crianca-viada>. Acessado em 11 de março de 2018.

DIAS, Tiago. Nós, LGBT, já fomos crianças e isso incomoda. Portal Entretenimento Uol, 2017. Disponível em: <https://entretenimento.uol.com.br/noticias/ redacao/2017/09/12/nos-lgbt-ja-fomos-criancas-esse-assunto-incomoda-diz-artista-acusada-de-pedofilia.htm>. Acessado em 11 de março de 2018.

FIDELIS, Gaudêncio. Não à censura. Revista Cult - Arte sob coerção, n. 230, ano 20. São Paulo: Bregantini, 2017.

FOUCAULT, Michel A Ordem do Discurso. Aula Inaugural no Collège de. France, pronunciada em 2 de dezembro de 1970. 19.ed. São Paulo: Edições. Loyola, 2009.

MESQUITA, André Luiz. Insurgências poéticas: arte ativista e ação coletiva (1990 - 2000). Universidade de São Paulo Instituto de Letras e Ciências Humanas, Pós-graduação em História, 2008.

NAME, Daniela. Não há arte possível para a gente de bem. Portal O Globo, 2017. Disponível em: <https://oglobo.globo.com/cultura/artes-visuais/artigo-nao-ha-arte-possivel-para-gente-de-bem-21810164>. Acessado em 11 de março de 2018.

PELBART, Peter Pál. Fala dos confins: o lugar da literatura na obra de Foucault. Revista Cult - Edição Especial Michel Foucault, n. 5, ano 18. São Paulo: Bregantini, 2015.

REVISTA CULT. Revista Cult - Arte sob coerção, n. 230, ano 20. São Paulo: Bregantini, 2017.

TEDESCO, Silvia. As práticas do dizer e os processos de subjetivação. Interação em Psicologia, jul./dez. 2006, (10)2, p. 357-362. Disponível em: <http://revistas.ufpr. br/psicologia/article/download/7694/5486>. Acessado em 02 de março de 2018.

TIBURI, Marcia. Arte e autoritarismo. Revista Cult - Arte sob coerção, n. 230, ano 20. São Paulo: Bregantini, 2017a.

TIBURI, Marcia. A negação de todos os poderes. Revista Cult - Arte sob coerção, n. 230, ano 20. São Paulo: Bregantini, 2017b. 
WARKEN, Júlia. Criança Viada: o que está por trás da obra que gerou revolta? Portal M de Mulher, 2017. Disponivel em: <https://mdemulher.abril.com.br/cultura/ crianca-viada-o-que-esta-por-tras-da-obra-que-gerou-revolta/>. Acessado em 11 de março de 2018. 